Int. J. Speleol. 16 (1987), pp. 33-58

\title{
Genetic analysis of evolutionary processes
}

\author{
Horst Wilkens *
}

\author{
SUMMARY
}

Epigean and cave populations of $A$. fasciatus (Characidae, Pisces) differ in a series of morphological, physiological, and ethological features. The interfertility of these populations made possible a genetic analysis of organs characteristic of interspecific divergence.

The study of the regressive organs "eye" and "melanophore system" on the one hand and that of the constructively improved "gustatory equipment " and "feeding behaviour" on the other yielded identical principles of genetic manifestation: (1) All features have a polygenic basis with an at least di- to hexahybrid inheritance. (2) All polygenes have the same amount of expressivity. (3) After recombination of a minimum number of genes, discontinuous distributions (threshold effects) develop. (4) All features are independently inherited. (5) The genes responsible for a feature are unspecific. In the case of the eye this means that no "lens-" or "retinagenes" are analyzed; due to developmentally physiological interdependence within complex structures, only so-called "eye-genes" have as yet been described.

Because of the developmentally physiological interdependence of complex organs, the process of reduction proceeds as a diminution in size, that of constructive evolution as enlargement. In both cases different allometric correlations of the single structures can be found.

The convergent reduction of eyes in cave animals is caused by the loss of stabilizing selection which normally keeps the eye in its appropriate adapted form. It is not directional selection pressure, like f. ex. energy economy, but mutation pressure that causes eye reduction. By this, random mutations, which are mostly of deleterious character are accumulated.

The principles of regressive evolution are not restricted to the development of cave species. The absence of stabilizing selection regularly occurs during transitional evolutionary phases. These are $f$. ex. initial stages of speciation which may be observed when biotopes with little or no interspecific competition are colonized by an invader. Genotypic and phenotypic variability now arise and equilibria become punctuated, because stabilizing selection for a specific ecological niche which has once

* Zoologisches Institut und Zoologisches Museum der Universität Hamburg, Martin-Luther-King-Platz 3, 2000 Hamburg 13. 
been acquired by the invading species is no longer acting. Examples include the evolution of species flocks in geologically young lakes or oceanic islands. Rapidly increasing variability now secondarily provides the material for directional selection which radiates such species into vacant niches. Genetic threshold effects as described above may accelerate this process. Variability will finally become lower again under the influence of inter- and intraspecific competition. A new equilibrium is attained.

\section{INTRODUCTION}

The concept of the theory of "Punctuated Equilibria" is that the history of life has been dominated by concentrated outbursts of rapid speciation rather than by slow, steady directional transformations (Newman et al., 1985; Lewin, 1986). Studying the explosive radiation of Cichlid fishes in the East African great lakes, especially that of Lake Victoria, Greenwood (1984) interprets the evolution of fish species flocks as an example of an extant punctuational phase.

The genetic analysis of the morphological changes has not yet been performed neither in the cichlids nor in any other examples of intralacustrine speciation. However, there are a lot of results from the study of the evolution of the different epi- and hypogean populations of the Mexican characin Astyanax fasciatus. It is the aim of this paper to demonstrate the similarity of these processes by applying the findings of the cave fish study.

\section{MORPHOLOGY OF EPIGEAN AND CAVE POPULATIONS OF A. FASCIATUS}

The very common epigean fish Astyanax fasciatus has developed a series of cave populations in Mexico. These populations diverge from their epigean ancestor by a large number of features, which have been subjected to regressive or constructive evolutionary processes (Mitchell et al., 1977).

The most obvious is the reduction of eyes and melanin pigmentation. The well-developed eye of the epigean fish has been reduced to a tiny rudiment in the cave form (fig. 1). Lens and visual cells are reduced during ontogeny. In a few eyes a retinal rudiment consisting of ganglionic, inner nuclear, and plexiform layers may be developed. In others even these have vanished (Peters \& Peters, 1966; Wilkens, 1970 a).

The light phenotype of the cave fish is caused by the reduction of the melanophore system. For this a lower number 


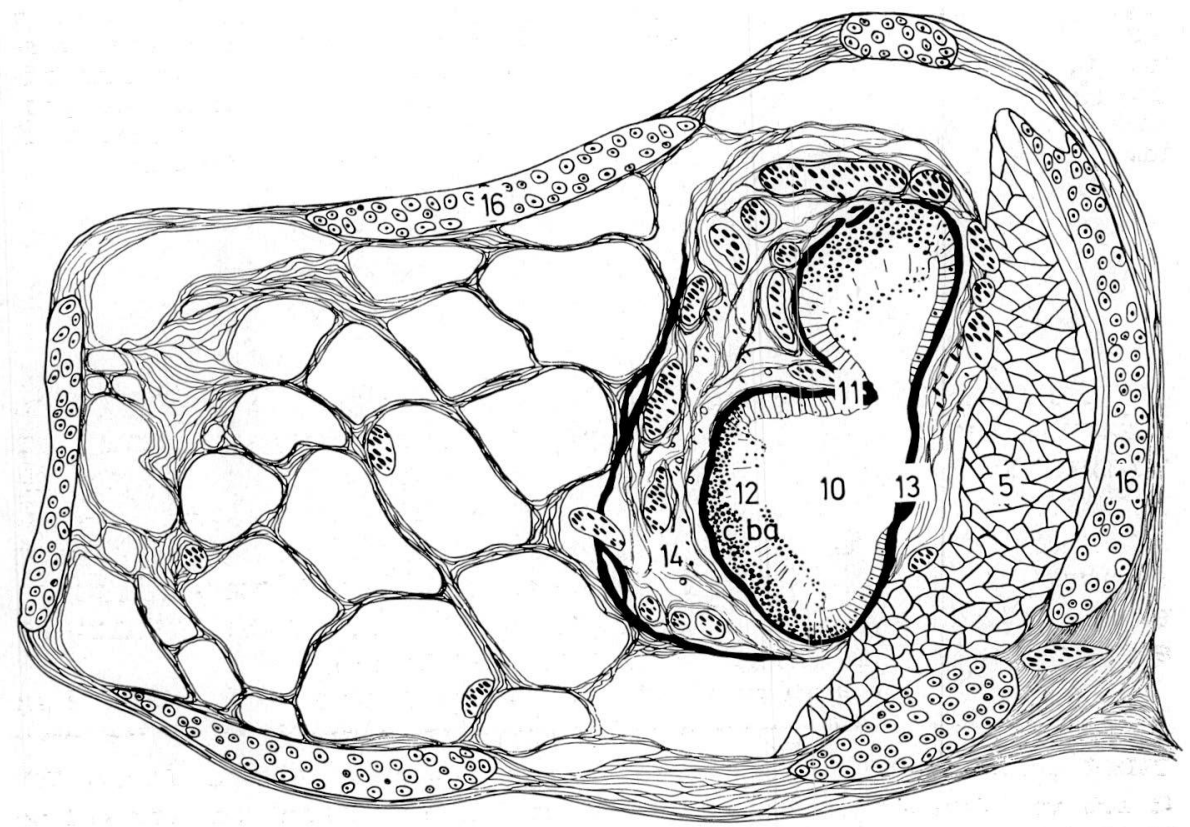

Fig. 1 - The eye rudiment of A. fasciatus (Population Cueva de El Pachón)

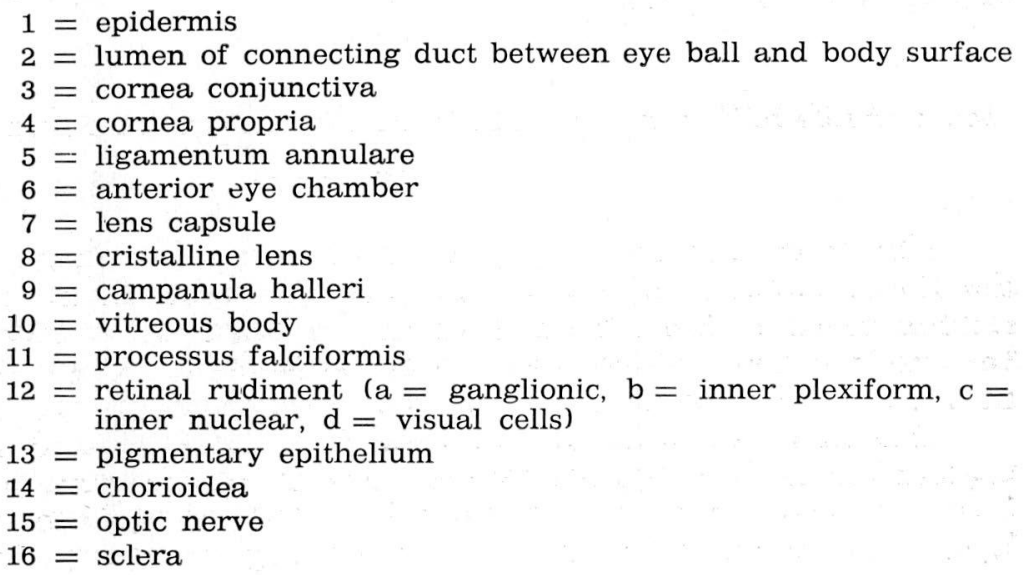

of melanophores, less melanin content, and loss of the ability of the morphological colour change are responsible (fig. 2) (Wilkens, 1970 b). 

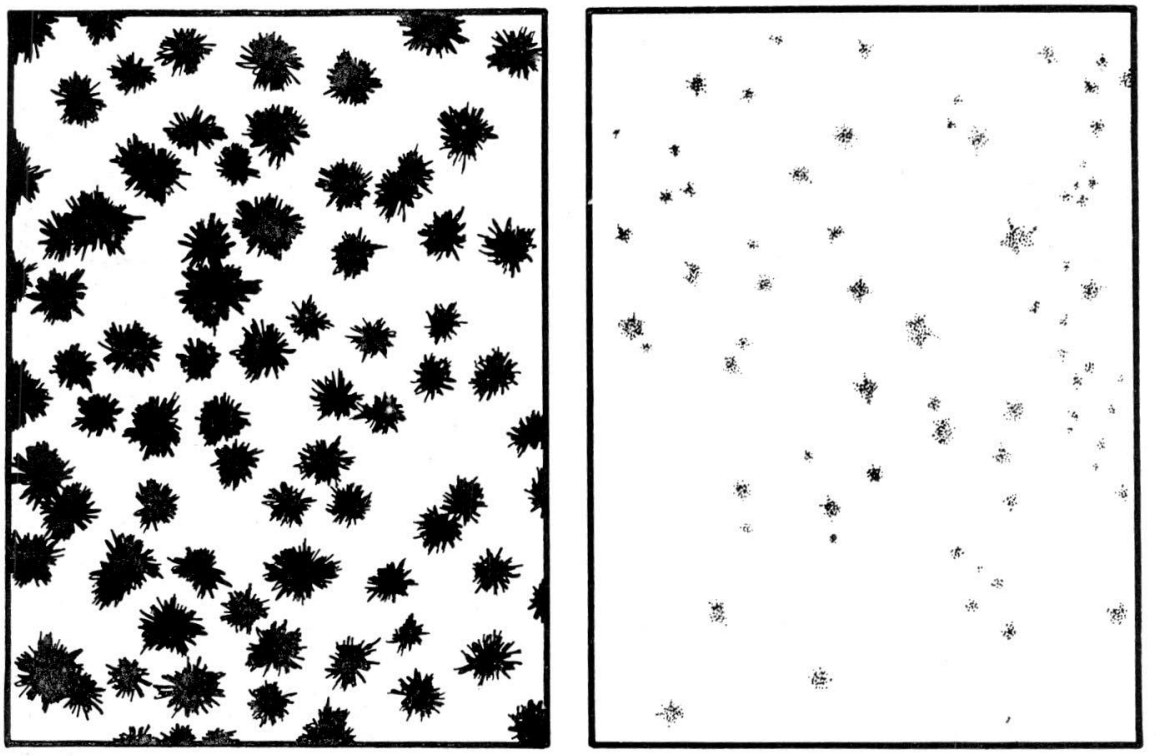

Fig. 2 - The melanophore system of epigean and hypogean A. fasciatus. In the cave population (right) the number of melanophores as well as their melanin content are reduced.

Contrary to the regressive organs eye and melanophore system, the gustatory equipment and the feeding behaviour are constructive adaptations to the cave biotope. The gustatory equipment of the epigean fish consists of an area of taste buds on the tips of the chin and lips. The area covered by these organs has been extended considerably especially on the ventral side of the head of the cave fish. Additionally, in one population the density of taste buds seems to have increased (Schemmel, 1967).

However, an appropriate and successful use of the improved gustatory equipment is only possible by an additional alteration of feeding behaviour. Without optic orientation epigean individuals feed in an $80^{\circ}$ angle to the bottom and are not very successful in food finding (Hüppop, this issue). Contrary to this, cave specimens feed in an angle of $55^{\circ}$. By this they can more efficiently use the gustatory apparatus while steadily swimming in close contact to the bottom searching for food (Schemmel, 1967; 1980). 


\section{GENETICS}

The divergences between epigean and cave populations have a genetic basis. Its analysis has been made possible by the interfertility of these forms (Sadoglu, 1956). Although eyes and melanophore system on the one hand are phylogenetically old organs, and gustatory equipment and feeding behaviour on the other are recently improved features, no fundamental differences of genetic manifestation were discovered. The principles of genetic manifestation of these features can be summarized in five points (Wilkens, 1980; 1984).

(1) All four features display polygenic inheritance. It is based on at least two factors regarding the gustatory equipment and up to at least six factors regarding the eye.

(2) All polygenes on principle show the same amount of expressivity. This can be concluded from the intermediate manifestation and from normal distribution of features in the $F_{1}$ - and $F_{2}$ - crossings (figs. $3,4,5,6$ ).

(3) A further common characteristic of all the polygenic systems in A. fasciatus is an alteration of the gene expressivity, called threshold effect (Rieger et al., 1968). Due to this phenomenon a discontinuous enlargement of a feature can be observed as described before (figs. 3, 4, 5, 6). The sudden enlargement only develops after a certain number of polygenes has been recombined. The threshold effect may increase the amount of manifestation considerably: the eye size f.ex. is discontinuously enlarged by about $17 \%$ (fig. 7).

It is characteristic of the features eye size, taste bud density and feeding behaviour that the threshold effect cannot be influenced by environment. The melanophore system diverges from this. In this organ the increase of colour cells is manifested only over dark not over light underground. Thus it is influenced by the environment. The threshold effect in this feature delivers the genetic basis of a common adaptation in fish, the morphological colour change.

The threshold effect described before is probably a very common principle of genetic manifestation.

In many examples monogenic inheritance may turn out to be based on the fact that one single polygene of high expressivity is acting while all other polygenes responsi- 

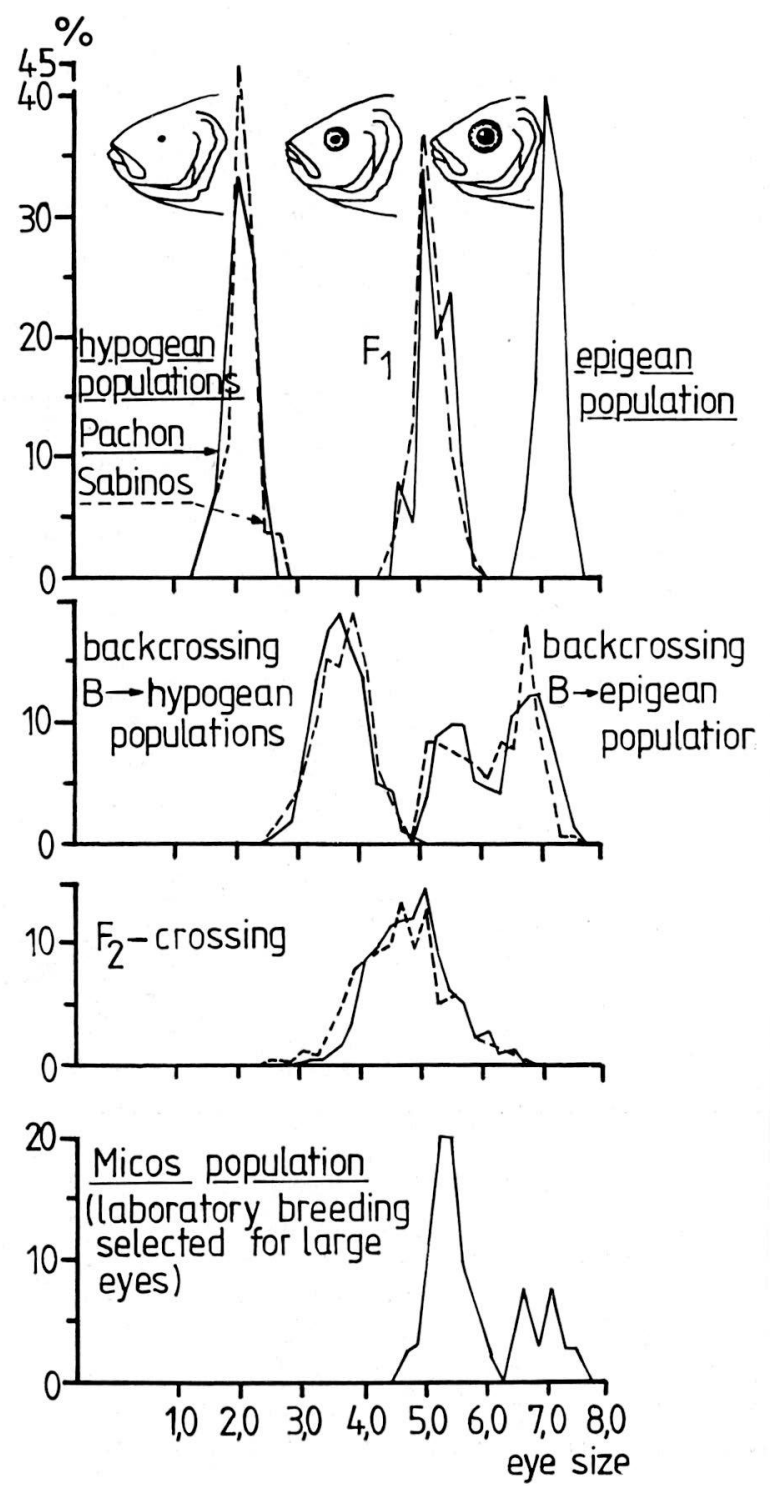

Fig. 3 - Distribution of eye size of different $A$. fasciatus populations and their crossings (Wilkens, 1970a, 1976, 1980). 


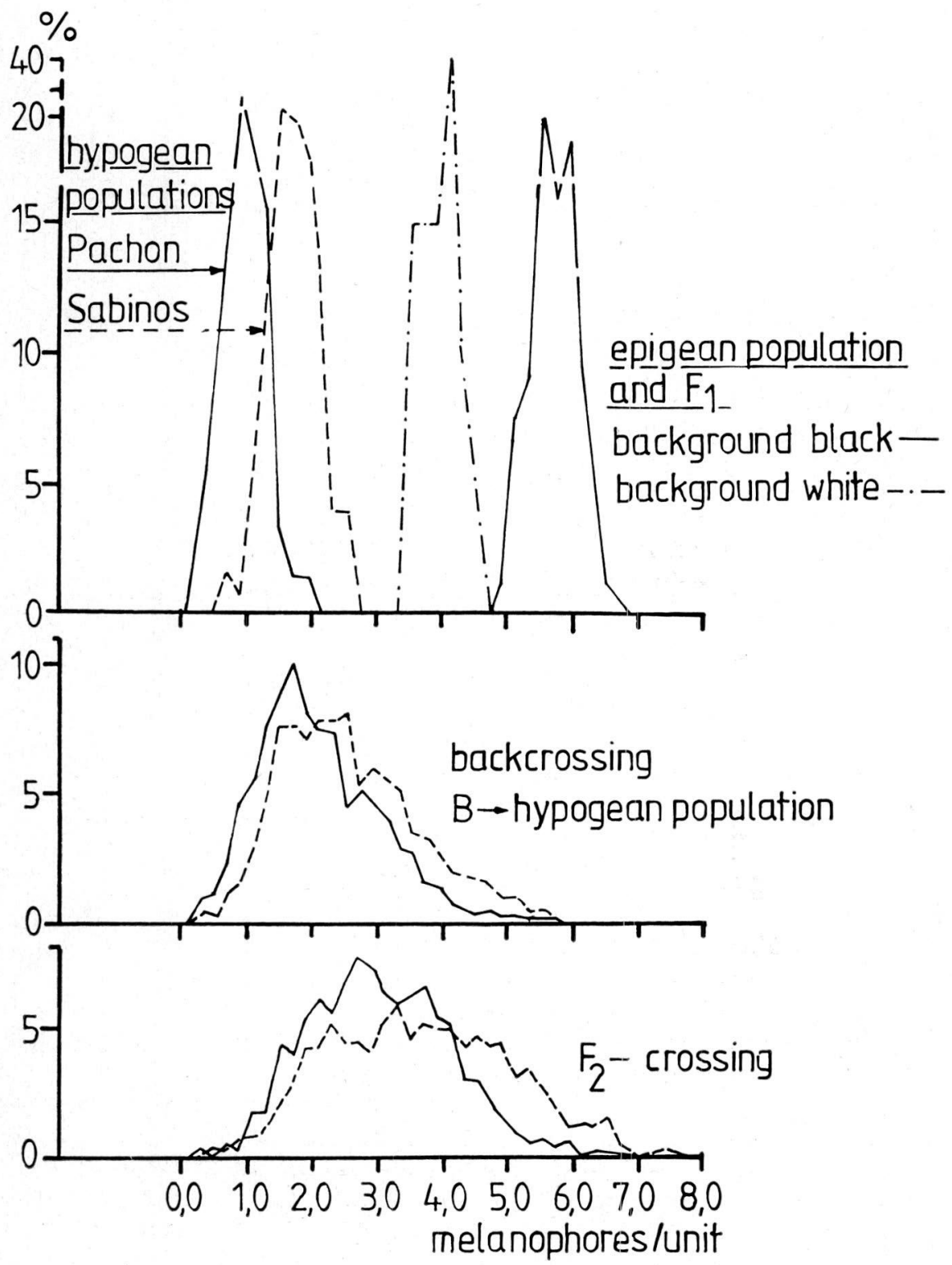

Fig. 4 - Distribution of melanophore densities of different $A_{\text {. }}$ fasciatus populations and their crossings (Wilkens, 1970c). 


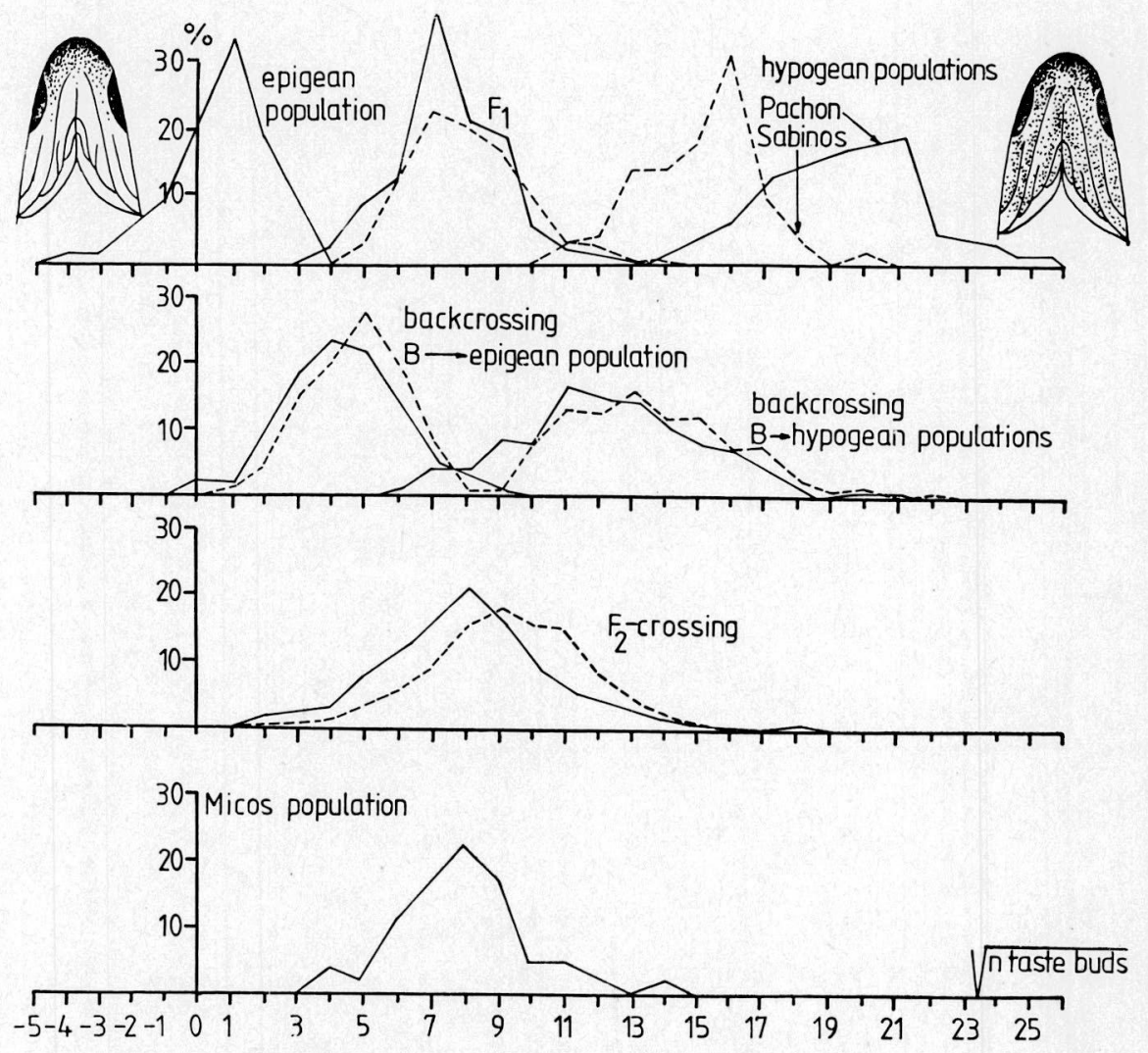

Fig. 5 - Distribution of taste bud density of various A. fasciatus populations and their crossings (Schemmel, 1974).

ble for the manifestation of a feature remain hidden because of too little structural difference.

An example for this is delivered by the sex determination within the toothcarp genus Xiphophorus (Kosswig, 1964; Kosswig \& Oktay, 1955). Here the transition from a merely polygenic (X. helleri) to a monogenic (X. maculatus) mechanism is clearly developed. The species X. cortezi is characterized by an intermediate stage with both modi side by side (Zander, 1965; 1986). In this form one of the male determining polygenes manifests high expressivity and delivers the basis of an apparently monogenic mechanism (Wilkens, 1980). 

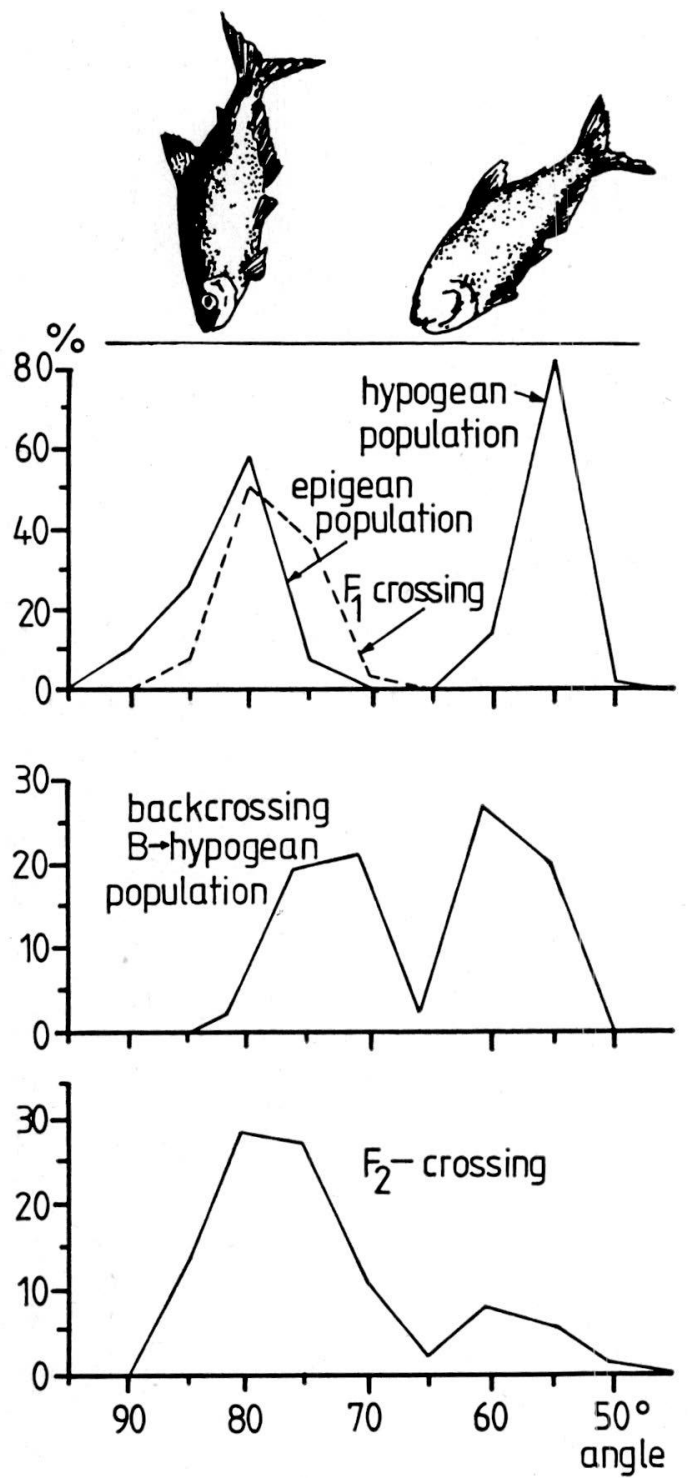

Fig. 6 - Distribution of feeding behaviour of various A. fasciatus populations and their crossings (Schemmel, 1980). 


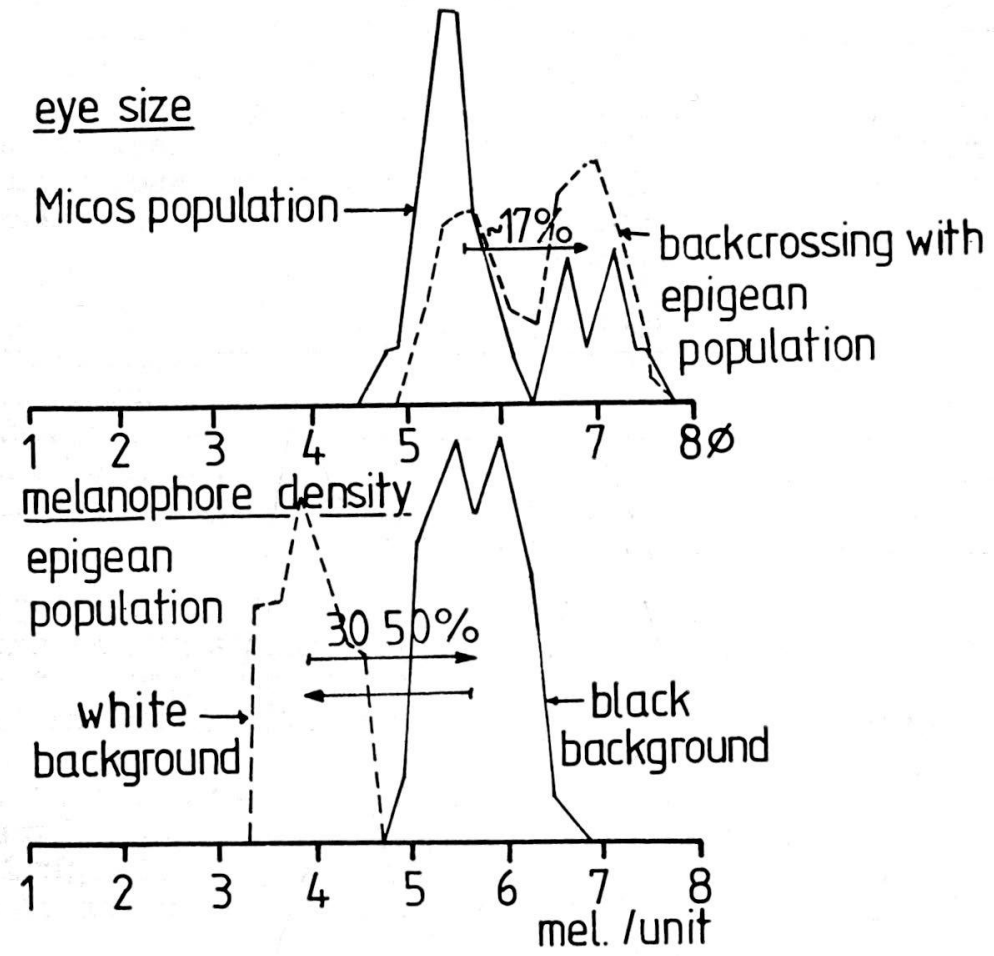

\section{feeding behaviour}

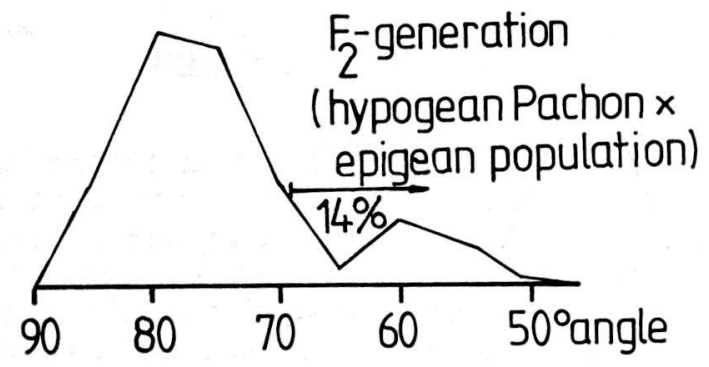

Fig. 7 - The threshold effect. After recombination of a minimum number of polygenes, which are responsible for the formation of a specific structure, gene expressivity changes. A structure may be improved by a considerable amount in one step (Wilkens, 1980). 
Phenotypic sex determination delivers a further example for the general validity of the threshold effect as a common principle of genetic manifestation. In Bonellia viridis (Echiurida), larvae which attach to a female proboscis will become male. Contrary to this, those which do not come in contact will become female specimens. This phenomenon is completely comparable to the morphological colour change of A. fasciatus, in which the threshold effect can also be suppressed environmentally.

(4) It is characteristic of the genetic manifestation of the complex features, which were studied in $A$. fasciatus, that the polygenic systems being responsible for their formation do not show linkage but inherit separately. Even gustatory equipment and feeding behaviour, which are functionally correlated to some degree, are inherited independently from each other (Schemmel, 1967; 1980).

(5) It is characteristic for all features studied that no polygenes responsible for specific single features can be analyzed. In the case of the eye for example no "lens-" or "retina-genes" have as yet been separated. Therefore the term "eye-gene" was coined. "Eye-genes", "melanophore-genes ", "taste-bud-genes" have a quantitative character and determine size respectively density. This method of manifestation is caused by the developmentally physiological interdependence of the single structures of complex organs (Wilkens, 1970 c; 1971).

\section{EVOLUTION OF COMPLEX FEATURES}

The developmental constraints within complex organs have been confirmed experimentally in the chicken eye (Coulombre, 1969). Ocular morphogenesis is regulated by the following main factors: (1) The size of the eye is determined by the dimension of the contact area of the optic vesicle with the surface ectoderm. Whenever it is smaller than normal a microphthalmic eye results. (2) The lens size is responsible for the accumulation of vitreous substance within the eye. It furthermore influences the normal growth and expansion of the superficial coats of the eye (pigmentary epithelium, chorioid coat, sclera). (3) The growth of the neural retina is relatively independent of any specific influence from other tissues. The neural retina influences the development of the pigmentary epithelium as well as the orientation and shape of the lens. 
Similar regulatory mechanisms are characteristic of the eye of A. fasciatus. The first anlage of this organ in the cave fish is much smaller than in epigean individuals (Cahn, 1958). The neural retina seems to grow rather independently (fig. $8 \mathrm{a}, \mathrm{b})$. The pigmentary epithelium will flatten after the sensory cells are reduced. Further insight was gained by calculating allometric correlations, which reflect developmental constraints between different tissues. Also in the $A$. fasciatus eye the lens obviously plays a dominant role. Its size is correlated with that of the eye ball as well as with that of the pupillary opening (fig. 9). It is worth noting that in all crossings the formative influence of the lens on eye size is less effective than in the epigean fish. This can be concluded from the fact that hybrid eye size only increases negatively allometrically in correlation to this organ (Wilkens, $1970 \mathrm{c}$ ).

In hybrid eyes as well as in those of the variable Micospopulation the degree of differentiation is correlated to the eye size. The larger an eye is, the better it is developed. In the $\mathrm{F}_{1}$-crossing between two extremely reduced cave populations individuals are found which have larger eyes. These may even develop structures like a lens capsule, which are never observed in the adult parental specimens (fig. 10) (Wilkens, 1971).

It seems in particular to be the relative size of an eye in comparison to body length that determines the degree of differentiation. This is clarified by similar tendencies of allometric correlation which are developed in eyes, the sizes of which have quite different causes (Wilkens, $1970 \mathrm{c}$ ). As could be examplified in the case of the lens of the crossings between the epigean and cave forms of $A$. fasciatus a positive allometric correlation is developed during individual ontogenetic growth as well as between eyes of different individuals the eye sizes of which are based on a different number of " eyegenes". This principle also holds true for the observation that larval cave fish eyes are better differentiated than those of adult specimens (Cahn, 1958; Peters \& Peters, 1973).

On account of developmentally physiological interdependence within complex organs no genes responsible for example for the formation of structures like retina or lens could as yet be determined for the eye. Although such genes probably exist, their loss by mutation will not only influence one specific organ but, on account of the developmental constraints, the whole eye. The phenotypic result is a smaller eye, which still possesses all typical single structures. From this it can be concluded that structural reduction quite generally will proceed as a process of diminution in size. Studies in cave animals have also shown that an important part of constructive adaptation may be the enlargement of relevant features. 

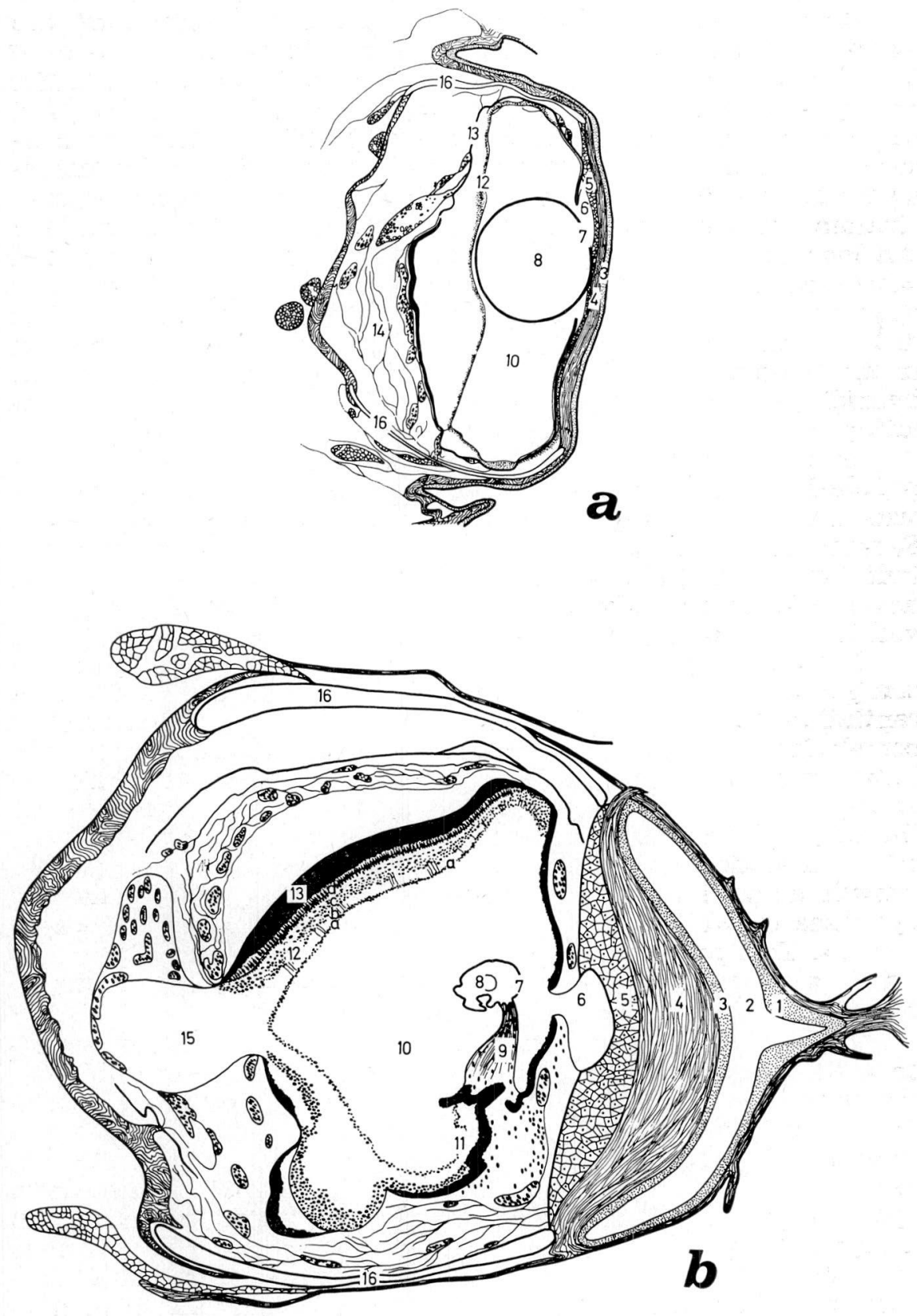

Fig. 8 - Even in large hybrid eyes the neural retina may secondarily dedifferentiate during late ontogeny (a). In others a rather well-developed retina is combined with a tiny lens rudiment (b). Thus a considerable developmental independency of this organ is proven (explanations fig. 1). 



Fig. 9 - Correlation of lens and pupillary opening sizes in the crossings between epigean and cave $A$. fasciatus (Standard length $2,5 \mathrm{~cm}$ ). 
These findings confirm assumptions that developmental contraints and interactions impose limits on the evolution of complex features (Alberch, 1980; 1982).

It is a fact of general evolutionary importance that, additionally to the enlargement or diminution of complex structures, the allometric regressions may change. Due to a reduced number and a different recombination of genes this occurs in the hybrid eyes of epigean and cave $A$. fasciatus. In the epigean form both lens and pupillary opening as well as eye ball size show isometric correlations. In the crossings, however, the correlation of lens and eye ball becomes positively allometric, that of lens and pupil negatively allometric. In the phylogenetically young Micos population, which is characterized by variable eye sizes, an intermediate stage is developed.

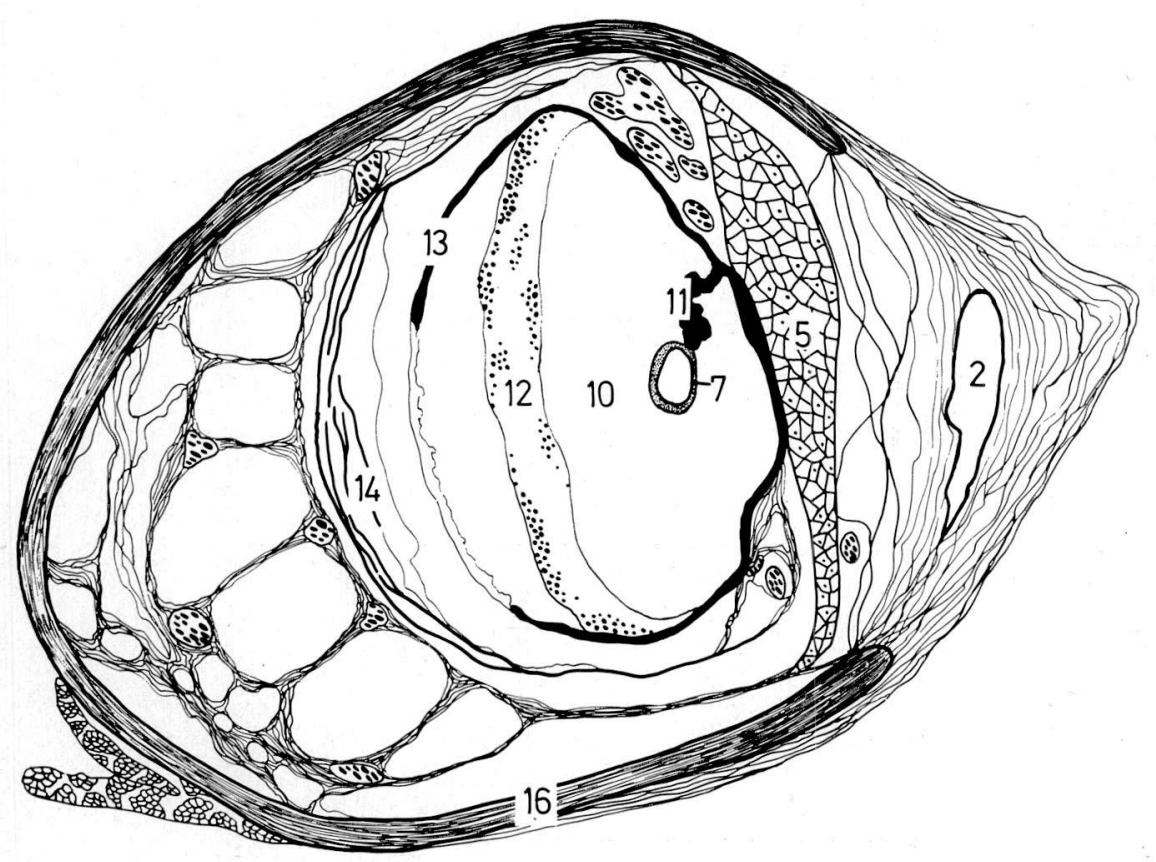

Fig. 10 - In some $F_{1}$-hybrids between extremely reduced cave populations eyes may develop which are larger and better differentiated than in the parental generation (explanations fig. 1). 


\section{MODE OF REGRESSIVE EVOLUTION}

It is a common evolutionary phenomenon that features which have lost their biological function are reduced. In many cases the process of reduction is promoted by directional selection. However, there are cases like the eye and pigment regression in many cave animals which are characterized by the fact that directional selection no longer acts. After the loss of stabilizing selection which normally keeps the eye in its appropriate adapted form by eliminating negative mutants, the deleterious mutations can accumulate. Eye and pigmentation now reduce by mutation pressure, because the number of such mutations is higher than those which improve an existing system.

In haemophilia for example stabilizing selection without medical help still eliminates negative mutations immediately, because they become lethal. Due to the mortality new negative mutations are necessary to account for the constant frequency of haemophilia, which can be observed in the human population (Haldane, 1935). Actua'ly one third of all casualties develop in families which before never did show haemophilia. These casualties therefore must be based on new mutations.

Until today the molecular nature of the negative mutations responsible for structural reduction has not been analyzed. However, molecular genetics of other features has provided insight. Studies of the bleeding disorder in man, haemophilia A, show that it is caused by defects in factor VIII, a component in the blood coagulation pathway. Gitschier et al. (1985) found that this disease is caused independently by 7 different mutations: 4 point mutations and 3 different partial deletions in the factor VIII gene. Also the clinically identical Tay-Sachs-disease of 2 different human populations turned out to be caused by different mutations (Myerowitz \& Hogikyan, 1986).

As a main objection against the theory of accumulation of random mutations, which is forwarded here, energy economy is thought by many authors (e.g. Sket, 1985) to play an important role as the directional selection force in structural reduction. Recent studies reveal that the cave fish have developed other and more efficient strategies against the at least temporary food scarcity of the cave biotope. By these they probably are able to spare much more energy than by eye reduction. The most important are adaptations like the increase of egg yolk content and lower metabolic rates (Hüppop, 1985; 1986 a, b; Poulson, 1985). Further proof for the theory of mutation pressure is delivered by ethological features like aggressive and schooling behaviour. Both are optically triggered and thus are not displayed in the epigean $A$. fasciatus when kept under cave conditions. Although there was no possibility for any kind of 
directional selection based on energy economy to reduce these non-manifested features, they show genetically based reduction (Burchards et al., 1986; Parzefall, 1985). The same is true for the circadian clock (Erckens \& Martin, 1982; Lamprecht \& Weber, 1985), which is reduced in the cave populations of $A$. fasciatus and in other troglobites.

After suggesting that several scientists had not done proper work, Bannister (1984)* recently supported the theory originally advanced by Heuts (1951), that characters of cavernicolous animals may be the result of neoteny. He examplified his assumption by the external observation that "the eyes in the adult "cave fish Garra barreimiae" are identical to those in the juvenile; they have not degenerated, they just have not developed further". Unfortunately the histological data have not been presented. As in all cave fish studied, they would have revealed the ontogenetic regression of this eye. As has been shown by Cahn (1958) in the A. fasciatus cave populations the first eye anlage is not only smaller but there are structures like the lens and parts of the retina which are reduced during the further ontogeny. Others like the ligamentum annulare or the processus falciformis relatively increase in size (Wilkens, 1970 a).

\section{GENERAL IMPORTANCE OF REGRESSIVE EVOLUTIONARY PRINCIPLES}

The principles of regressive evolution as described before also have general validity for constructive evolution. The lack of stabilizing selection occurs not only in biologically functionless features of cave animals, but can also be observed during transitional evolutionary phases (Wilkens et al. 1979; Wilkens, 1986).

Examples for this are delivered by the evolution of species flocks in geologically young lakes or in islands. These biota are characterized by depauperate faunas, which are caused by a geographically isolated position or - in the case of lakes - by an unusual ionic composition of the water (Ladiges, 1968; Wilkens, 1986). Lakes like the great East African lakes, the Laguna de Chichancanab (Yucatan) or the Cuatro Cienagas (Chihuahua) characterized by intralacustrine fish speciation deviate from the normal chemical freshwater composition (fig. 11). Invading fish species can find here various niches not claimed by other fish. Thus stabilizing selection for the relevant adap-

* The confusing and, to a large part unjustified, critique shall be refuted in another paper. 


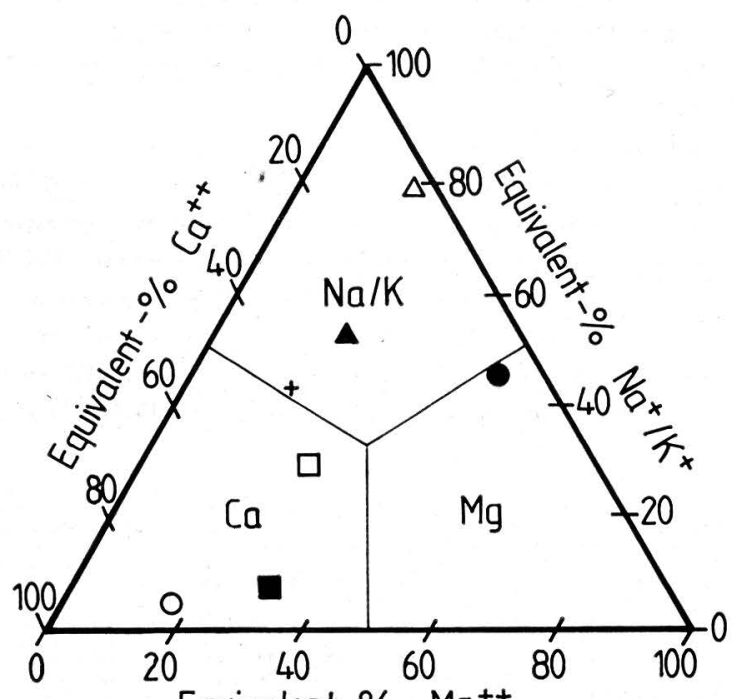

Equivalent-\% $\mathrm{Mg}^{++}$

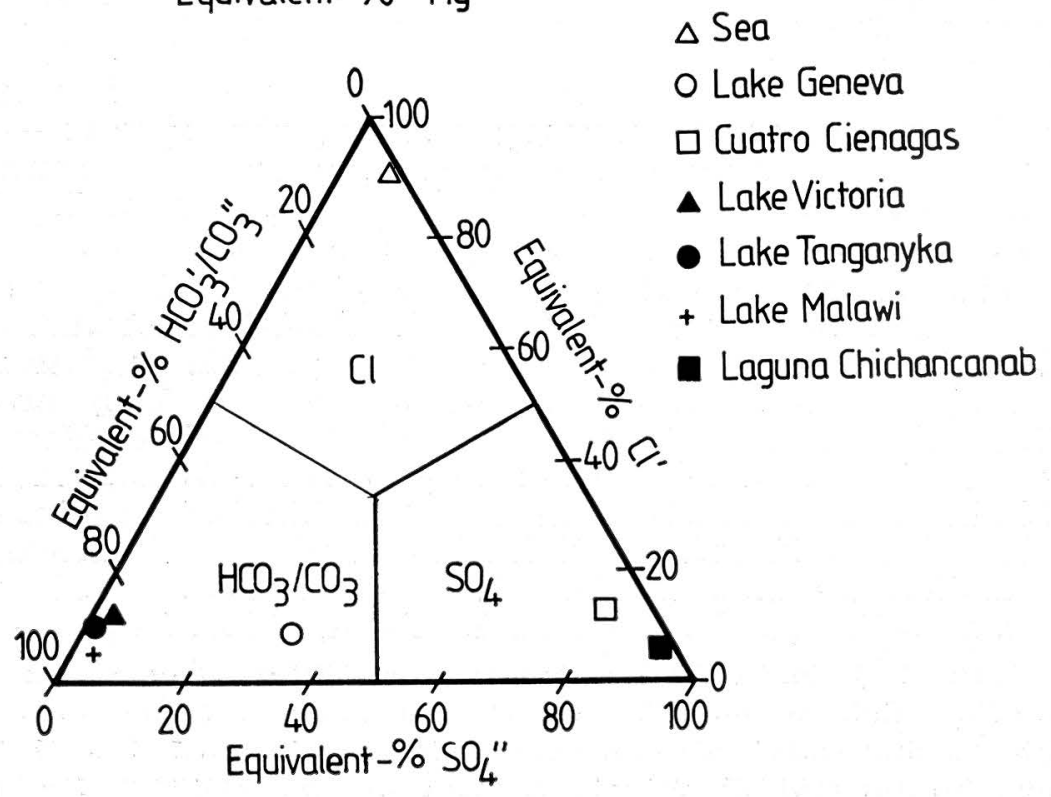

Fig. 11 - Ionic composition of lakes with species flocks in comparison to the sea and Lake Geneva (modified after Grimm, 1986). 
tations of the specific niche which the invading species once had acquired is lost. By this equilibria become punctuated. Variability arises and may persist, because there are no competing species in the niches which are taken advantage of the developing species flock.

For example, variability of shape arises. It is caused by random mutations which may provoke genetically based heterochronic changes in development and slight alterations of growth rates of the single structures of complex organs. In East African Lake Victoria haplochromine cichlids, the relative sizes and shapes of many of these fish lie in simple allometric relationships with one another and very often the differences between species are extrapolations of those within species (Greenwood, 1984).

Such variability is "allowed" as long as, and to the extent that, the viability of an individual is not influenced. Observations in the above mentioned cichlid species flock show that general body form develops only a little diversity (fig. 12) (Grenwood, 1984; Strauss, 1984). However, because empty trophic niches were available developing cranial and dental differences could persist. Those are the main features in the speciation of these fishes (fig. 13).

Based on Lack's (1947) studies of Darwin's finches of the Galapagos Islands, Kosswig (1948 a) showed that - although already adapted to several new niches - some of them are still characterized by little specialization to the food they live on and by structural variability of their bills.

The arising variability is not only restricted by viability. As has been shown before, developmental constraints also play an important role. Theoretically possible evolutionary pathways in many cases are family specific. They are limited as concerns the direction and the number (Kosswig, 1948 b; Alberch, 1980; 1982). In respect to specialized pharyngeal characters the molariform morph of Cichlasoma minckleyi of the Cuatro Cienagas (Chihuahua) for example resembles the mollusc crashing cichlids of East Africa more closely than its conspecific papilliform morph (Liem \& Kaufman, 1984).

The only difference between the colonization of the niche-rich lakes or islands on the one hand and the cave biotope on the other is that the latter only offers one vacant niche which closely resembles that of the epigean ancestor. Thus variability is only "allowed " to those few features which have become functionless. Contrary to this, there is strong directional selection pressure on those which are most important for survival under extreme environmental conditions, as they are characteristic of the cave biotope. 


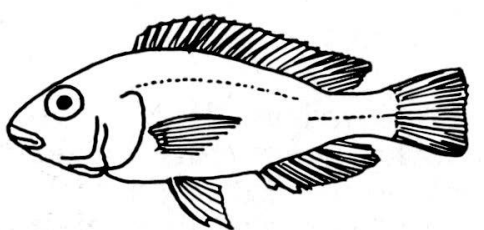

bottom feeder

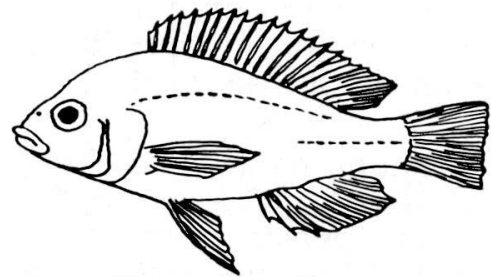

mollusc eater

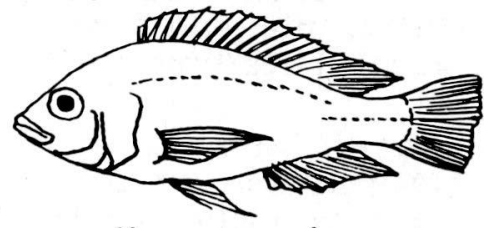

mollusc eater

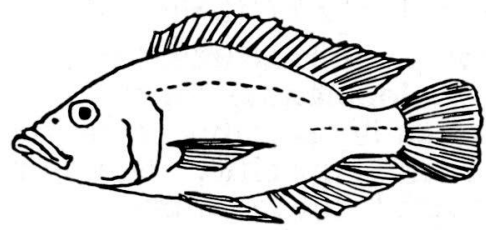

piscivore

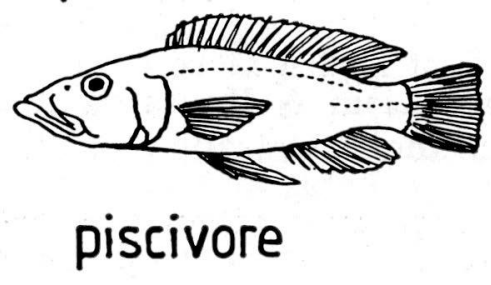

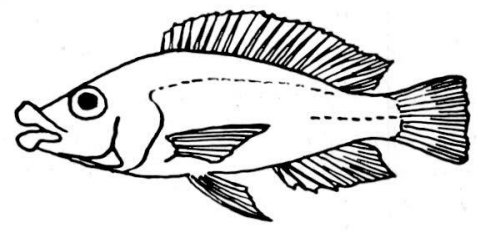

insectivore

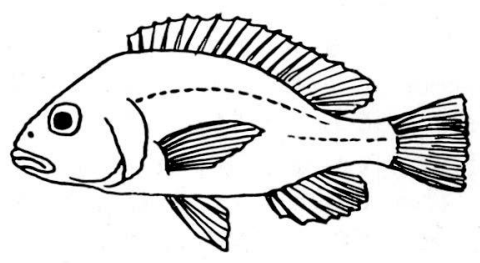

detritus eater

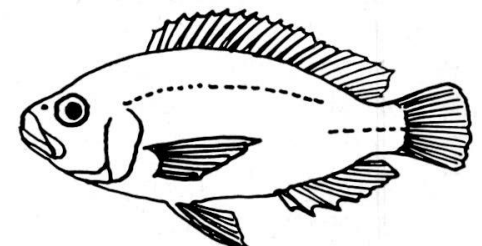

paedophage

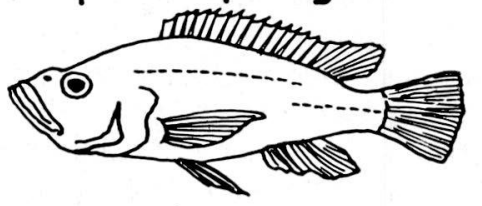

piscivore

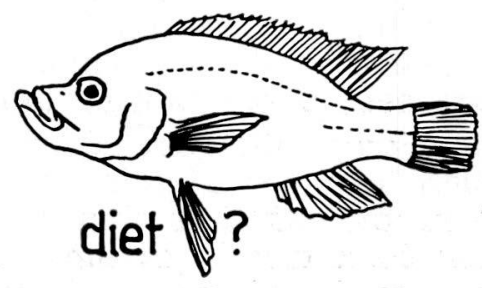

Fig. 12 - Body form in various Lake Victoria haplochromines (Greenwood, 1984). 

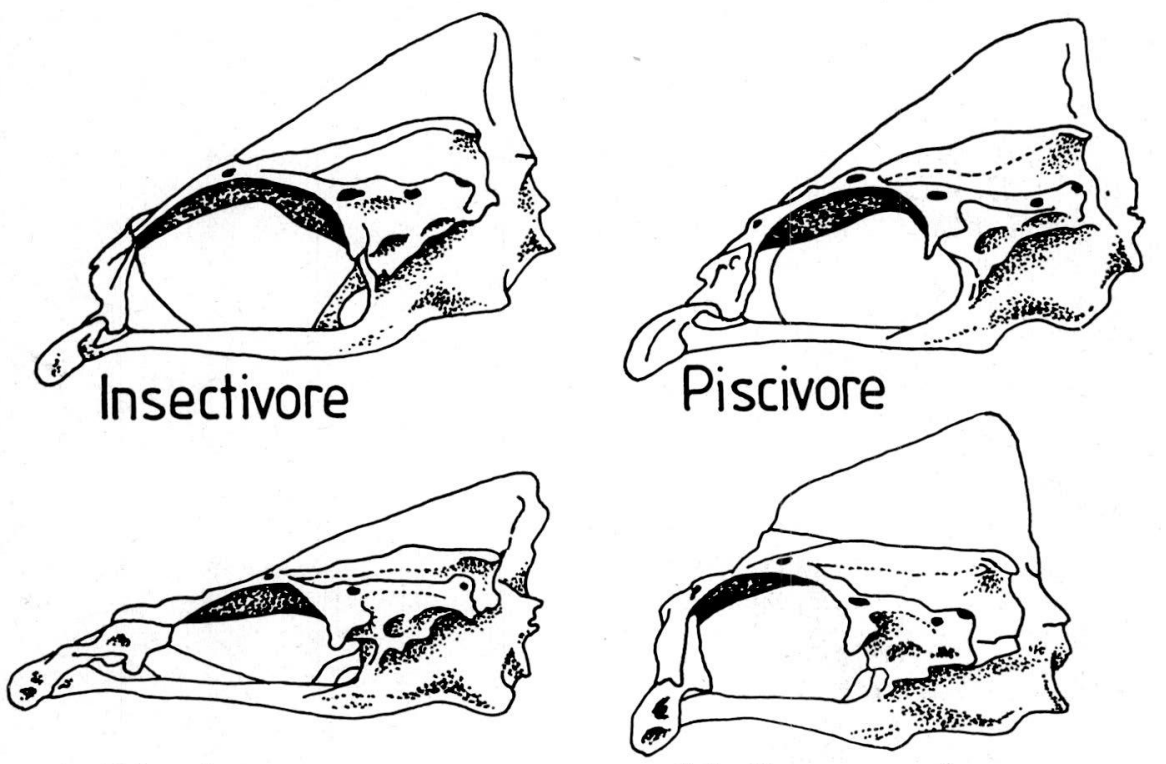

Piscivore Mollusc eater

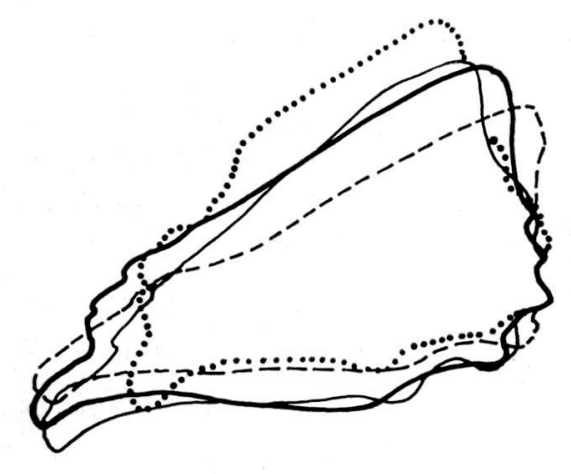

Fig. 13 - Skull form in various Lake Victoria haplochromines (Greenwood, 1984).

Uprising variability in species flocks delivers the material for directional selection which radiates such species into free niches. It will finally lower again under the influence of intra- and interspecific competition. Genetic threshold effects as described before may play an important role in accelerating this process. Finally a new static equilibrium is attained. Besides the spectrum of available free niches the number of 
developing species is determined by ethological characteristics of the ancestral species. In cichlids, homogamy is probably responsible for the overwhelming number of forms (Kosswig, 1963; Dominey, 1984).

Even the time necessary for these processes is comparable. In the Lake Victoria cichlids, previously referred to the genus Haplochromis (Greenwood, 1984) a time of about 750.000 years is assumed for their speciation. The evolution of most cave populations of $A$. fasciatus originally described as an own genus "Anoptichthys" also started during Pleistocene.

Species flocks deliver examples of extant punctuational phases (Greenwood, 1984). As has been shown, the evolution of species flocks can be explained by the same developmentally physiological and genetical principles as that of cave animals. These are polygenetically based differences, slight alterations of allometric correlations and loss of stabilizing selection for certain features. Punctuational events therefore are not contradictive, but are also subjected to gradual change.

\section{ACKNOWLEDGEMENTS}

I am grateful to Prof. Sbordoni for making it possible to give this lecture.

I thank Monika Hänel (Zoologisches Institut und Zoologisches Museum, Universität Hamburg) for kindly drawing the figures.

\section{REFERENCES}

ALBERCH, P. 1980. Ontogenesis and morphological divergence. Amer. Zool. 20: $613-667$.

ALBERCH, P. 1982. Developmental constraints in evolutionary processes, p. 313-332. In J. Bonner (ed.), Evolution and Development.

BANNISTER, K.E. 1984. A subterranean population of Garra barreimiae (Teleostei: Cyprinidae) from Oman, with comments on the concept of regressive evolution. Journ. Nat. Hist. 18: 927-938.

BURCHARDS, H., A. DOLLE \& J. PARZEFALL. 1985. Aggressive behaviour of an epigean population of Astyanax mexicanus (Characidae, Pisces) and some observations on three subterranean populations. Behav. Proc. 11: 225-235. 
CAHN, P.H. 1958. Comparative optic development in Astyanax mexicanus and in two of its blind cave derivatives. Bull. Am. Mus. Nat. Hist. 115 (2): 71-112.

COULOMBRE, A.J. 1969. Regulation of ocular morphogenesis. Invest. Ophthalmology 8 (1): 25-31.

DOMINEY, W.J. 1984. Effects of sexual selection and life history on speciation: Species flocks in African cichlids and Hawaiian Drosophila, p. 231-249. In A.A. Echelle \& J. Kornfield (eds), Evolution of fish species flocks.

ERCKENS, W. \& W. MARTIN. 1982. Exogeneous and endogeneous control of swimming activity in Astyanax mexicanus (Characidae, Pisces) by direct light response and by a circadian oscillator. II. Features of time controlled behaviour of a cave population and their comparison to an epigean ancestral form. Z. Naturforsch. 37C: 1266-1273.

GITSCHIER, J., W.J. WOOD, E.G.D. TUDDENHAM, M.A. SCHUMAN, T.M. GORALKA, E.Y. CHEN \& R.M. LAWN. 1985. Detection and sequence of mutations in the factor VIII gene of haemophiliacs. Nature 315: 427-430.

GREENWOOD, P.H. 1984. African cichlids and evolutionary theories, p. 141-154. In A.A. Echelle \& J. Kornfield (eds.), Evolution of fish species flocks.

GRIMM, H. 1986. Ionenbilanzen - graphisch dargestellt. Naturwissenschaften im Unterricht - Physik/Chemie 19: 39-40.

HALDANE, J.B.S. 1935. The rate of spontaneous mutation of a human gene. J. Genet. 31: 317-326.

HEUTS, M.J. 1951. Ecology, variation and adaptation of the blind cave fish Caecobarbus geertsi Blgr. Ann. Soc. Roy. Zool. Belg. 82: 155-230.

HUPPOP, K. 1985. The role of metabolism in the evolution of cave animals. The NSS Bulletin 47: 136-146.

HUPPOP, K. 1986 a. Oxygen consumption of Astyanax fasciatus (Characidae, Pisces): A comparison of epigean and hypogean populations. Envir. Biol. 17: 299-308.

HUPPOP, K. 1986 b. Comparative early life history in surface and cave fish (Astyanax fasciatus). Boll. Zool. 53 Suppl.: 104 (Abstract only).

HUPPOP, K. 1987. Food-finding ability in Astyanax fasciatus. Int. J. Speleol. 16: 59-66.

KOSSWIG, C. 1948 a. Genetische Beiträge zur Präadaptationstheorie. Istanbul Universitesi Fen Fac. Mecmuasi, B 13: 176-209.

KOSSWIG, C. 1948 b. Homologe und analoge Gene, parallele Evolution und Konvergenz. Com. Fac. Sciences de l'Universitesi Ankara. 1: 126-177.

KOSSWIG, C. 1963. Ways of speciation in fishes. Copeia 2: 238-244.

KOSSWIG, C. 1964. Polygenic sex determination. Experientia 20: 1-10.

KOSSWIG, C. \& M. OKTAY. 1955. Die Geschlechtsbestimmung bei den Xiphophorini. (Neue Tatsachen und neue Deutungen). Istanbul Universitesi Fen Fac. Hidrobiol. B 2: 133-156.

LACK, D. 1947. Darwin's Finches. Cambridge Univ. Press., Cambridge, 240 pp.

LADIGES, W. 1968. Die Bedeutung ökologischer Faktoren für die Differenzierung der Cichliden des Tanganjika- und des Nyassa-Sees. Int. Rev. ges. Hydrobiol. 52: 339-352.

LAMPRECHT, G. \& F. WEBER, 1985. Time keeping mechanisms and their ecological significance in cavernicolous animals. The NSS Bulletin 47 (2): 147-162.

LEWIN, R. 1986. Punctuated Equilibrium is an old hat. Science 231: 672-673.

LIEM, K.J. \& L.S. KAUFMAN. 1984. Intraspecific macro-evolution: Functional biology of the polymorphic cichlid species Cichlasoma minckleyi, p. 203-215. In A.A. Echelle \& J. Kornfield (eds.), Evolution of fish species flocks. 
MITCHELL, R.W., W.H. RUSSELL \& W.R. ELLIOTT. 1977. Mexican eyeless Characin fishes, genus Astyanax: Environment, distribution, and evolution. Spec. Publ. Mus. Texas Tech. University 12: 1-89.

MYEROWITZ, R. \& N.D. HOGIKYAN, 1986. Different mutations in Ashkenazi Jewish and Non-Jewish French Canadians with Tay-Sachs disease. Science 232: 1646-1648.

NEWMAN, C.M., J.E. COHEN \& C. KNIPIS. 1985. Neo-darwinian evolution implies punctuated equilibria. Nature: 400-401.

PARZEFALL, J. 1985. On the heredity of behaviour patterns in cave animals and their epigean relatives. The NSS Bulletin 47 (2): 128-135.

PETERS, N. \& G. PETERS. 1966. Das Auge zweier Höhlenformen von Astyanax mexicanus Philippi (Characidae, Pisces). Wilh. Roux' Arch. Entwicklungsmech. Org. 157: 393-414.

PETERS, N. \& G. PETERS. 1973. Genetic problems in the regressive evolution of cavernicolous fish, p. 187-201. In J.H. Schröder (ed.), Genetics and Mutagenesis of Fish, Springer Verlag, Heidelberg.

POULSON, T.L. 1985. Evolutionary reduction by neutral mutations: Plausibility arguments and data from amblyopsid fishes and linyphiid spiders. The NSS Bulletin 47 (2): 109-117.

RIEGER, R., A. MICHAELIS \& M.M. GREEN. 1968. A glossary of genetics and cytogenetics. Springer Berlin, Hamburg, New York. 1-500.

SADOGLU, P. 1956. A preliminary report on the genetics of the Mexican cave characins. Copeia 1956: 113-114.

SCHEMMEL, C. 1967. Vergleichende Untersuchungen an den Hautsinnesorganen ober - und unterirdisch lebender Astyanax-Formen. Z. Morph. Tiere 61: 255-316.

SCHEMMEL, C. 1974. Genetische Untersuchungen zur Evolution des Geschmacksapparates bei cavernicolen Fischen. Z. zool. Syst. Evolut.-forsch. 12: 196-215.

SCHEMMEL, C. 1980. Studies on the genetics of feeding behaviour in the cave fish Astyanax mexicanus f. Anoptichthys. An example of apparent monofactorial inheritance by polygenes. Z. Tierpsychol. 53: 9-22.

SKET, B. 1985. Why all cave animals do not look alike - a discussion on adaptive value of reduction processes. The NSS Bulletin 47(2): 78-85.

STRAUSS, R.E. 1984. Allometry and functional feeding morphology in haplochromine cichlids, p. 217-299. In A.A. Echelle \& J. Kornfield (eds.), Evolution of fish species flocks.

WILKENS, H. 1970 a. Der Bau des Augas cavernicoler Sippen von Astyanax fasciatus (Characidae, Pisces). Beitrag zur Problematik degenerativer Evolutions prozesse. Wilh. Roux' Arch. Entwicklungsmech. Org. 166: 54-75.

WILKENS, H. 1970 b. Beiträge zur Degeneration des Melaninpigments bei cavernicolen Sippen des Astyanax mexicanus (Filippi) (Characidae, Pisces). Z. zool. Syst. Evolut.-forsch. 8: 173-199.

WILKENS, H. 1970 c. Beiträge zur Degeneration des Auges bei Cavernicolen, Genzahl und Manifestationsart. Z. zool. Syst. Evolut.-forsch. 8: $1-47$.

WILKENS, H. 1971. Genetic interpretation of regressive evolutionary processes: Studies on hybrid eyes of two Astyanax cave populations (Characidae, Pisces). Evolution 25: 530-544.

WILKENS, H. 1976. Genotypic and phenotypic variability in cave animals. Studies on a phylogenetically young cave population of Astyanax mexicanus (Filippi). Ann. Spéléol. 31: 137-148.

WILKENS, H. 1980. Prinzipien der Manifestation polygener Systeme. Z. zool. Syst. Evolut.-forsch. 18: 103-111.

WILKENS, H. 1984. Zur Evolution von Polygensystemen, untersucht an ober- und unterirdischen Populationen des Astyanax mexicanus (Characidae, Pisces). Z. zool. Syst. Evolut.-forsch. Beiheft 3: 55-71. 
WILKENS, H. 1986. The evolution of polygenic systems. Studies on epigean and cave populations of Astyanax fasciatus (Characidae, Pisces). The NSS Bulletin 47 (2): 101-108.

WILKENS, H., N. PETERS \& C. SCHEMMEL. 1979. Gesetzmäßigkeiten der regressiven Evolution. Verh. Dtsch. Zool. Ges.: 124-140.

ZANDER, C.-D. 1965. Die Geschlechtsbestimmung bei Xiphophorus montezumae cortezi Rosen (Pisces). Z. Vererbgsl. 96: 128-141.

ZANDER, C.-D. 1986. Die Jalapa-Population des Schwertträgers Xiphophorus helleri Heckel (Pisces, Poeciliidae) als Modell für die Evolution des Heterochromosoms. Z. Zool. Syst. Evolut.-forsch. 24: 129-138. 